\title{
Analisis Pengaruh Budaya Organisasi, Disiplin Kerja Serta Semangat Kerja Terhadap Kinerja Karyawan pada \\ PT. Ediral Tritunggal Perkasa Kantor \\ Cikande Serang
}

\author{
Syamsudin ${ }^{(1)}$ \\ syamsudinunsera@gmail.com \\ Ratu Erlina Gentari ${ }^{(2)}$ \\ ratu_gentari@yahoo.co.id \\ Suhartini ${ }^{(3)}$ \\ suhartini@unpas.ac.id
}

Fakultas Ekonomi dan Bisnis, Universitas Serang Raya

\begin{abstract}
ABSTRAK
Dalam meningkatkan kinerja karyawan, perusahaan menempuh beberapa cara misalnya melalui peningkatan budaya organisasi, peningkatan disiplin kerja, serta peningkatan semangat kerja yang lebih biak. Penelitian ini bertujuan untuk mengetahui pengaruh budaya organisasi, didiplin kerja, dan semangat kerja terhadap kinerja karyawan PT. Ediral Tritunggal Perkasa Kantor Cikande. Beberapa masalah yang timbul pada PT. Ediral Tritunggal Perkasa yaitu banyaknya karyawan yang masih terlambat untuk masuk kerja, kurangnya mematuhi peraturan yaang ada pada perusahaan, serta terjadinya penurunan semangat kerja yang diakibatkan faktor usia pada karyawan yang bekerja di perusahaaan tersebut. Penelitian ini menggunakan Budaya Organisasi, Disiplin Kerja dan Semangat Kerja sebagai variabel independen serta Kinerja Karyawan sebagai variabel dependen. Sampel yang digunakan adalah Karyawan PT. Ediral Tritunggal Perkasa sebanyak 80 responden, dengan metode sampel jenuh. Analisis yang digunakan meliputi uji reabilitas, uji validitas, uji asumsi klasik, Analisis regresi berganda, dan Uji hipotesis. Hasil penelitian menunjukkan bahwa budaya organisasi, disiplin kerja serta semangat kerja berpengaruh terhadap kinerja karyawan. Berdasarkan hasil pengolahan data bahwa angka Adjusted R square sebesar 0,778 menunjukkan bahwa kinerja karyawan di PT. Ediral Tritunggal Perkasa berhubungan erat dengan ketiga variabel bebas. Variabel budaya organisasi memiliki t hitung 13,720 dengan signifikasi 0,000, variabel disiplin kerja memiliki t hitung sebesar 2,482 dengan signifikasi 0,015 dan variabel semangat kerja memiliki t hitung 3,951 dengan signifikasi 0,000.
\end{abstract}

Kata Kunci : Budaya Organisasi, Disiplin Kerja, Semangat Kerja, Kinerja Karyawan.

\section{ABSTRACT}

In improving employee performance, the company pursues several ways, for example through enhancing organizational culture, increasing work discipline, and increasing the work morale. This study aims to determine the influence of organizational culture, work disipline, and work spirit on the performance of employees of PT Ediral Tritunggal Perkasa Cikande Office. Some problems that arise in PT Ediral Tritunggal Perkasa is the 
number of employees who are still late to enter work, lack of compliance with the rules that exist in the company, as well as a decrease in morale due to the age factor of employees working in the company.This study uses Organizational Culture, Work Discipline and Work Spirit as independent variables and Employee Performance as the dependent variable. The sample used is PT Ediral Tritunggal Perkasa is 80 respindens, with saturated sample methods. The analysis used includes reliability test, validity test, classic assumption test, multiple regression analysis, and hypothesis testing. The results of the study showed that organizational culture, work discipline and morale influenced employee performance. Based on the results of data processing that the number of adjusted $R$ square of 0.778 indicates that the performance of employees at PT Mighty Ediral Trinity is closely related to the three independent variables. Organizational culture variables have a count of 13.720 with a significance of 0.000 , the variable work discipline has a t count of 2.482 with a significance of 0.015 and the variable morale has a tcount of 3.951 with a significance of 0.000 .

Keywords: Organizational Culture, Work Disipline, Work Spirit, Employee Performance

\section{PENDAHULUAN}

Di era globalisasi manajemen sumber daya manusia merupakan faktor pemegang peranan yang sangat strategis dan menentukan setiap perusahaan selalu mengharapkan sumber daya yang mampu bekerja secara efektif dan efisien agar mencapai tujuan yang ditentukan. Hal ini menunjukkan bahwa sumber daya manusia merupakan kunci pokok yang harus diperhatikan dalam segala kebutuhan. Sumber daya manusia yang efektif dan efisien melalui kegiatan perencanaan, penggerakkan, dan pengendalian suatu nilai yang menjadi kekuatan manusia untuk mencapai tujuan. Oleh karena itu manajemen sumber daya manusia sangatlah penting dalam suatu perusahaan sehingga suatu organisasi dituntut untuk mencapai suatu tujuan yang diinginkan.

Sumber daya manusia merupakan modal yang menentukan keunggulan kompetitif dan keberhasilan untuk mencapai sebuah tujuan perusahaan. Untuk mencapai tujuan tersebut diperlukan kemauan, kemampuan dan sikap pegawai baik dalam melaksanakan tugas dan tanggung jawab, sehingga hasil kerja pegawai yang dilakukan bisa sesuai dengan tujuan perusahaan. Dalam mengelola sumber daya manusia berbagai permasalahan akan sering muncul, seperti kinerja karyawan yang kurang maksimal.

Peningkatan kualitas kinerja karyawan selalu diharapkan oleh setiap perusahaan. PT Ediral Tritunggal Perkasa kantor Cikande senantiasa berusaha dengan berbagai metode peningkatan kualitas produktivitas dengan pelatihan, pengembangan kinerja karyawan, dan sebagainya. Hal tersebut dilakukan oleh perusahaan untuk menciptakan budaya kerja yang baik dan meningkatkan kedisiplinan pegawai dalam melakukan pekerjaannya. Apa yang dirasakan pegawai dan bagaimana persepsi ini menciptakan suatu pola teladan, kepercayaan, nilai-nilai dan harapan adalah budaya organisasi. Tidak hanya budaya organisasi saja yang menentukan tingkat keberhasilan perusahan, tentunya juga didukung oleh banyaknya peraturan dan ketentuan yang mengatur dan membatasi setiap kegiatan dan 
perilaku didalam perusahaan. Hal tersebut bisa tercapai jika semua pegawai menjunjung tinggi kedisiplinan.

Untuk menciptakan budaya organisasi yang baik, PT Ediral Trirunggal Perkasa kantor Cikande membuat slogan yang berisi tentang motivasi diantaranya adalah :

1. Rajin

2. Ringkas

3. Rapih

4. Resik

5. Rawat

Penerapan disiplin dalam perusahaan tetap harus diupayakan dengan cara-cara yang baik, efisien dan efektif, oleh karena itu perlu diketahui apakah hakikat disiplin itu sendiri. Seperti masuk dan pulang kerja yang lebih diperketat, tidak ada titip absen pada teman. Hal ini karena sistem absen sudah menggunakan sidik jari.

Berdasarkan hasil observasi yang dilakukan penulis memperhatikan budaya organisasi yang ada kurang maksimal dan berjalan kurang baik seperti tidak disiplinnya karyawan untuk bekerja, sebagai contoh ketika bel masuk seharusnya karyawan memulai pekerjaan tapi sebaliknya mereka bersantai untuk menikmati sarapan atau sekedar berbincang dengan yang lainnya. Sedangkan untuk disiplin kerjanya karyawan kurang mematuhi peraturan yang ada pada perusahaan seperti kedisiplinan waktu yang lemah karena tidak ada punishment (hukuman) misalnya karyawan sering terlambat itu hanya mendapat surat teguran, tidak ada yang sifatnya mengurangi.

Begitu pula dengan semangat kerja karyawan yang menurun karena faktor usia yang menjadi penghambat proses kerja karyawan. Oleh karena itu kinerja karyawan menjadi lambat dan hasil kerja yang dilakukan karyawan tersebut tidak susuai dengan pencapaian target yang ditentukan perusahaan.

Berdasarkan uraian diatas maka penulis tertarik untuk melakukan penelitian dengan judul : "ANALISISPENGARUH BUDAYA ORGANISASI, DISIPLIN KERJA SERTA SEMANGAT KERJA TERHADAP KINERJA KARYAWAN"

\section{LANDASAN TEORI}

\section{BUDAYA ORGANISASI}

Budaya organisasi diartikan sebagai seperangkat perilaku, perasaan, dan kerangka psikologis yang terinterminasi yang mendalam dan dimiliki bersama oleh anggota organisasi (Asang, 2012). Secara umum, suatu perusahaan atau organisasi terdiri atas sejumlah orang yang memiliki berbagai latar belakang, kepribadian, emosi, dan ego. Hasil dari penjumlahan dan interaksi berbagai orang tersebut membentuk suatu budaya organisasi. Secara sederhana, budaya organisasi dapat didefinisikan sebagai suatu kesatuan orang-orang (beliefs), dan nilai-nilai yang sama. 
Budaya organisasi merupakan seperangkat nilai-nilai, keyakinan, dan sikap utama yang diberlakukan diantara anggota organisasi. Budaya yang dapat menyesuaikan serta mendorong keterlibatan karyawan dapat memperjelas tujuan dan arah strategi organisasi serta yang selalu menguraikan dan mengajarkan nilai-nilai dan keyakinan organisasi, dapat membantu organisasi mencapai pertumbuhan penjualan, pengembalian modal, keuntungan, mutu dan kepuasan pelanggan yang lebih tinggi (Darmawan, 2013). Jadi, jika dalam suatu organisasi tidak mempunyai budaya yang dominan dan hanya terdiri dari banyak sub budaya, maka pengaruh dari budaya terhadap keefektifan organisasi akan jauh lebih tidak jelas dan tidak akan terdapat konsistensi didalam persepsi atau perilaku Menurut Robbins, (2013) budaya organisasi adalah suatu sistem dari makna atau arti bersama yang dianut para anggotanya yang membedakan organisasi dari organisasi lain. Sedangkan Menurut Suharsono, (2012) menyatakan bahwa budaya organisasi adalah perilaku konvensional masyarakatnya dan mempengaruhi perilaku anggotanya meskipun sebagian besar tidak disadarinya.

\section{DISIPLIN KERJA}

Menurut Barnawi dan Arifin (2012), Disiplin kerja adalah kemampuan kerja seseorang untuk secara teratur, tekun, terus-menerus, dan bekerja sesuai dengan aturan-aturan yang berlaku dengan tidak melanggar aturan-aturan yang sudah diterapkan. Kedisiplinan dapat diartikan bilamana pegawai datang dan pulang tepat waktunya, mengerjakan semua pekerjaannya dengan baik, mematuhi semua peraturan dan norma-norma sosial yang berlaku.

Sedangkan Menurut Heidjrachman dan Husnan dalaam Sinambela (2012), Disiplin adalah setiap perseorangan dan juga kelompok yang menjamin adanya kepatuhan “ perintah" dan berinisiatif untuk melakukan suatu tindakan yang diperlukan seandainya tidak ada "perintah".

Berdasarkan pendapat-pendapat tersebut, dapat disimpulkan bahwa disiplin kerja pegawai merupakan sikap atau tingkah laku yang menunjukkan kesetiaan dan ketaatan seseorang atau sekelompok orang terhadap peraturan yang telah ditetapkan oleh organisasinya baik yang tertulis maupun tidak tertulis sehingga diharapkan pekerjaan yang dilakukan efektif dan efisien.

Tujuan utama disiplin kerja adalah demi kelangsungan organisasi atau perusahaan sesuai dengan tujuan organisasi atau perusahaan yaang bersangkutan. Secara khusus tujuan disiplin kerja para pegawai antara lain :

1. Agar pegawai menepati segala peraturan dan kebijakan ketenagakerjaan maupun peraturan dan kebijakan organisasi yang berlaku, baik tertulis maupun tidak tertulis, serta melaksanakan perintah manajemen yang baik.

2. Pegawai dapat melaksanakan pekerjaan dengan sebaik-baiknya serta mampu memberikan pelayanan yang maksimum kepada pihak tertentu yang berkepentingan dengan organisasi sesuai dengan bidang pekerjaan yang diberikan kepadanya 
kemudian pegawai dapat menggunakan dan memelihara sarana dan prasarana, barang dan jasa organisasi dengan sebaik-baiknya.

3. Para pegawai dapat bertindak dan berpartisipasi sesuai dengan norma-norma yang berlaku pada organisasi dan pegawai mampu menghasilkan produktivitas yang tinggi sesuai dengan harapan organisasi, baik dalam jangka pendek maupun jangka panjang (Rivai, 2013).

\section{SEMANGAT KERJA}

Menurut Melayu SP. Hasibuan (2010), mengemukakan bahwa semangat kerja adalah keinginan dan kesungguhan seseorang mengerjakan pekerjaannya dengan baik serta berdisiplin untuk mencapai produktivitas yang maksimal. Semangat kerja akan merangsang seseorang untuk berkarya dan berkreativitas dalam pekerjaan. Semangat kerja merupakan sikap individu untuk melakukan pekerjaan dengan giat, bekerja sama, berdisiplin, bertanggung jawab sehingga pekerjaan dapat dilaksanakan dengan lebih cepat dan lebih baik, maka dapat dikatakan bahwa semangat kerja sangat berkaitan dengan suasana atau keadaan dimana sikap dan perasaan dari seseorang atau kelompok orang yang merasa terikat untuk melakukan pekerjaannya.

Sedangkan Menurut Purwanto (2012), menyatakan bahwa “ Semangat kerja adalah reaksi emosional dan mental dari seseorang terhadap pekerjaannya. Semangat kerja mempengaruhi kualitas dan kuantitas pekerjaan seseorang”.

Dari definisi diatas dapat disimpulkan bahwa semangat kerja merupakan cermin dari kondisi pegawai dalam lingkungan kerjanya dan ekspresi serta mental individu atau kelompok yang menunjukan rasa senang dan bahagia dalam melakukan pekerjaanya, sehingga merasa bergairah dan mampu bekerja secara lebih cepat dan lebih baik demi tercapainya suatu tujuan kelompok maupun organisasi. Jika semangat kerja meningkat maka perusahaan akan memperoleh banyak keuntungan seperti rendahnya tingkat absensi, pekerjaan lebih cepat diselesaikan dan sebagainya.sehinggan tingkat kedisiplinan kerja dapat ditingkatkan.

\section{KINERJA KARYAWAN}

Kinerja dalam bahasa inggris disebut dengan job perfomance atau actual perfomance atau level of perfomance, yang merupakan tingkat keberhasilan pegawai dalam menyelesaikan pekerjaannya. Menurut Hersey dan Blanchard dalam Sinambela (2012), kinerja merupakan suatu fungsi dari motivasi dan kemampuan untuk mencapai hasil kerja yang optimal dalam suatu organisasi.

Menurut Rivai (2013), kinerja adalah suatu fungsi dari motivasi dan kemampuan dalam menyelesaikan tugas atau pekerjaan yang telah dibebankan kepada seseorang serta sepatutnya memiliki derajat kesediaan dan tingkat kemampuan tertentu yang dimiliki tertentu yang dimiliki oleh seseorang. 
Sinambela (2016), mengemukakan bahwa kinerja merupakan kesediaan seseorang atau kelompok untuk melakukan suatu kegiatan dan menyempurnakannya sesuai dengan tanggung jawabnya dengan hasil seperti yang diharapkan.

Menurut Wibowo (2015), kinerja adalah tentang bagaimana melakukan sesuatu pekerjaan dan hasil yang dicapai atau diperoleh dari pekerjaan tersebut. Kinerja adalah tentang apa yang dipekerjaan dan bagaimana cara mengerjakannya.

Berdasarkan uraian diatas dapat disimpulkan bahwa kinerja merupakan hasil kerja secara kualitas dan kuantitas yang dicapai oleh seorang pegawai dalam melaksanakan tugasnya sesuai dengan tanggung jawab yang diberikan kepadanya.

\section{KERANGKA BERPIKIR}

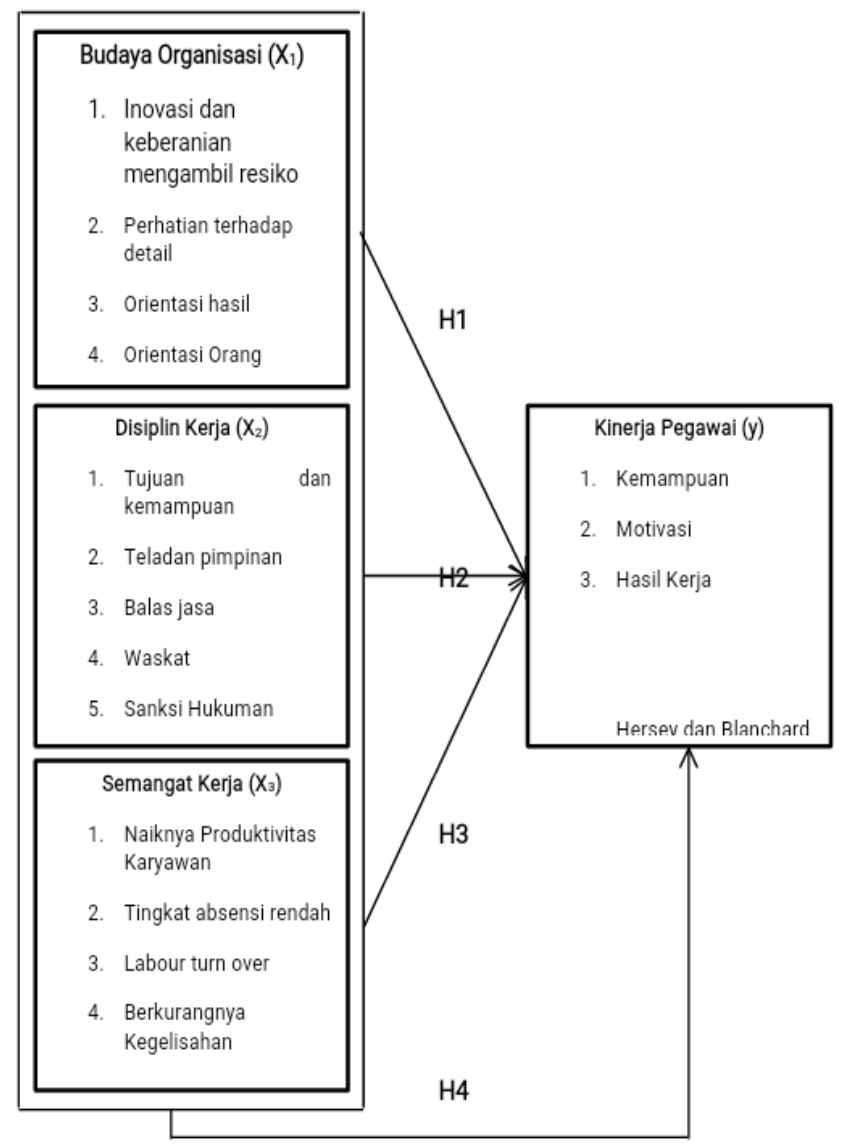

\section{PERUMUSAN HIPOTESIS}

1. H1 : Diduga analisis pengaruh budaya organisasi berpengaruh signifikan terhadap kinerja pegawai pada PT. Ediral Tritunggal Perkasa.

2. H2 : Diduga analisis pengaruh Disiplin Kerja berpengaruh signifikan terhadap kinerja pegawai pada PT. Ediral Tritunggal Perkasa. 
3. H3 : Diduga analisis pengaruh Semangat Kerja berpengaruh signifikan terhadap kinerja pegawai pada PT. Ediral Tritunggal Perkasa.

4. H4 : Diduga analisis pengaruh budaya organisasi, disiplin kerja, serta semangat kerja berpengaruh signifikan terhadap kinerja pegawai pada PT. Ediral Tritunggal Perkasa.

\section{METODE PENELITIAN}

\section{Populasi dan Sample}

Sampel adalah bagian dari jumlah dan karakteristik yang dimiliki oleh populasi tersebut (Sugiyono,2013). Populasi dalam penelitian ini adalah seluruh pegawai pada PT. Ediral Tritunggal Perkasa kantor Cikande yaitu terdapat 88 orang dan seluruhnya merupakan responden mengingat jumlah populasi yang relatif sedikit, sehingga teknik sampling yang digunakan adalah nonprobability sampling yaitu sampling jenuh. Sampel ditentukan sebanyak 88 orang (Sampling Jenuh).

\section{Analisis Regresi Berganda}

Menurut sunyoto (2011), Analisis regresi berganda untuk mengetahui ada tidaknya pengaruh signifikan dua atau lebih variabel bebas $(\mathrm{X} 1, \mathrm{X} 2, \mathrm{X} 3, \ldots . ., \mathrm{Xn})$ terhadap variaabel terikat (Y). Rumusnya adalah sebagai berikut :

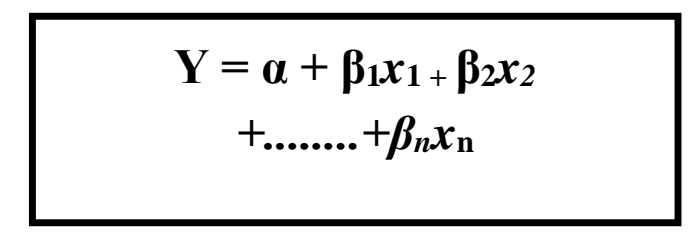

Dimana :

$$
\begin{array}{ll}
\mathrm{Y} & \multicolumn{1}{c}{\text { Kinerja }} \\
\alpha & =\text { Konstanta } \\
\mathrm{X}_{1} & =\text { Budaya Organisasi } \\
\mathrm{X}_{2} & =\text { Disiplin Kerja } \\
\mathrm{b}_{\mathrm{n}} & =\text { Koefisien Regresi Variabel }
\end{array}
$$

\section{Pengujian Hipotesis}

\section{Uji t}

Uji t digunakan menunjukkan seberapa jauh pengaruh satu variabel bebas secara parsial dalam menerangkan variasi variabel terikat. Kriteria pengambilan keputusan dilakukan dengan cara membandingkannya $r$ hitung dengan tabel, dimana hipotesis 
alternatif diterima jika : $\mathrm{t}$ hitung $>\mathrm{t}$ tabel dengan tingkat signifikan 0,05. Untuk menentukan nilai t tabel dilakukan dengan terlebih dahulu mencari derajat/ df (degree of freedom) dengan rumus $\mathrm{df}=\mathrm{n}-\mathrm{k}$, dimana $\mathrm{n}$ adalah observasi sedangkan $\mathrm{k}$ adalah banyaknya variabel (bebas dan terikat).

\section{Uji f}

Uji f disebut juga uji signifikansi serentak (uji simultan). Uji f merupakan uji yang digunakan untuk menguji besarnya pengaruh dari seluruh variabel independen secara bersama-sama terhadap variabel dependen. Uji statistik $f$ dapat dilakukan dengan membandingkan antara $F_{\text {hitung }}$ dengan $F_{\text {tabel }}$ jika $\mathrm{F}_{\text {hitung }}>\mathrm{F}_{\text {tabel }}$ maka hipotesis alternatif diterima (model layak digunakan), demikian pula sebaliknya. Taraf nyata yang digunakan sebesar 5\%. Dalam penelitian ini digunakan tingkat signifikansi $(\alpha)$ 0,05 atau 5\% untuk menguji apakah hipotesis yang diajukan dalam penelitian ini diterima atau ditolak dilakukan dngan cara menguji nilai f. Apabila nilai $f$ positif berarti hipotesis diterima jika nilai $\mathrm{f}$ negatif berarti hipotesis ditolak.

\section{HASIL DAN PEMBAHASAN}

\section{Analisis Regresi Berganda}

Analisis regresi adalah analisis yang di lakukan untuk mengukur besarnya pengaruh variabel bebas terhadap variabel terikat. Perhitungan analisis regresi menggunakan program SPSS 21 dan adapun model kelayakan regresi linear di dasarkan pada hal-hal sebagai berikut:

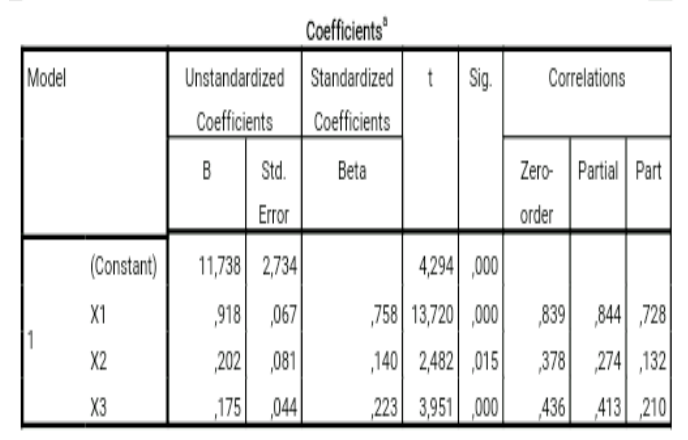

(Sumber : Hasil Pengolahan Data SPSS V.21).

Dari tabel tersebut maka diperoleh persamaan regresi sebagai berikut :

$$
\begin{gathered}
\hat{Y}=\mathrm{a}+\mathrm{b}_{1}\left(\mathrm{X}_{1}\right)+\mathrm{b}_{2}\left(\mathrm{X}_{2}\right)+\mathrm{b}_{3}\left(\mathrm{X}_{3}\right)+\mathrm{e} \\
\widehat{Y}=11.738+0,918\left(\mathrm{X}_{1}\right)+0,202\left(\mathrm{X}_{2}\right)+0,175\left(\mathrm{X}_{3}\right)+\mathrm{e}
\end{gathered}
$$

Persamaan regresi tersebut mempunyai interpretasi sebagai berikut :

1) Konstanta (a) sebesar 11,738 menyatakan bahwa Budaya Organisasi, Disiplin Kerja dan Semangat Kerja adalah = 0, maka Kinerja Karyawan naik sebesar 11,738.

2) Koefisien regresi untuk Budaya Organisasi sebesar 0,918 dan bertanda positif, hal ini berarti bahwa setiap kenaikan 1 pada Budaya Organisasi, maka Kinerja Karyawan 
akan mengalami kenaikan sebesar 0,918.

3) Koefisien regresi untuk Disiplin Kerja sebesar 0,202 dan bertanda positif, hal ini berarti bahwa setiap kenaikan 1 pada Disiplin Kerja, maka Kinerja Karyawan akan mengalami kenaikan sebesar 0,202.

4) Koefisien regresi untuk Semangat Kerja sebesar 0,175 dan bertanda positif, hal ini berarti bahwa setiap kenaikan 1 pada Semangat Kerja, maka Kinerja Karyawan akan mengalami kenaikan sebesar 0,175 .

Uji t

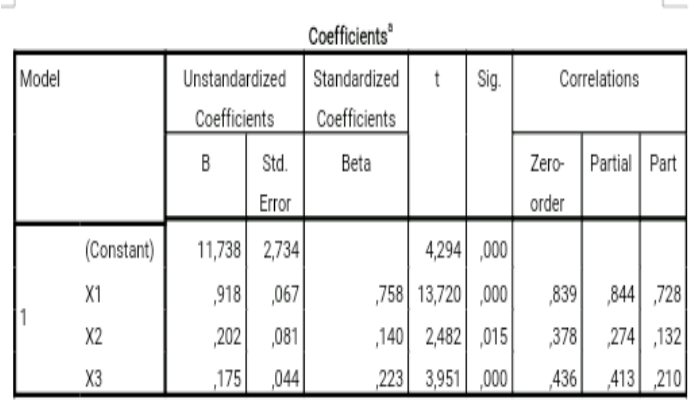

(Sumber : Hasil Pengolahan Data SPSS V.21).

1. Berdasarkan tabel output coefficients di atas, maka dapat di ketahui bahwa nilai koefisien regresi variabel Budaya Organisasi $\left(X_{1}\right)$ adalah sebesar 13,720> 1,6 bernilai positif karena thitung $>$ tabel, sehingga dapat di katakan bahwa Budaya Organisasi $\left(\mathrm{X}_{1}\right)$ berpengaruh positif dan signifikan terhadap Kinerja karyawan $(\mathrm{Y})$.

2. Berdasarkan tabel output coefficients di atas, maka dapat di ketahui bahwa nilai koefisien regresi variabel disiplin Kerja $\left(\mathrm{X}_{2}\right)$ adalah sebesar 2,482> 1,6 bernilai positif karena thitung $>$ ttabel, sehingga dapat di katakan bahwa Disiplin Kerja $\left(\mathrm{X}_{2}\right)$ berpengaruh positif dan signifikan terhadap Kinerja karyawan (Y).

3. Berdasarkan tabel output coefficients di atas, maka dapat di ketahui bahwa nilai koefisien regresi variabel Semangat Kerja $\left(\mathrm{X}_{3}\right)$ adalah sebesar 3,951> 1,6 bernilai positif karena thitung >ttabel, sehingga dapat di katakan bahwa Semangat Kerja $\left(\mathrm{X}_{3}\right)$ berpengaruh positif dan signifikan terhadap Kinerja karyawan $(\mathrm{Y})$.

Uji f

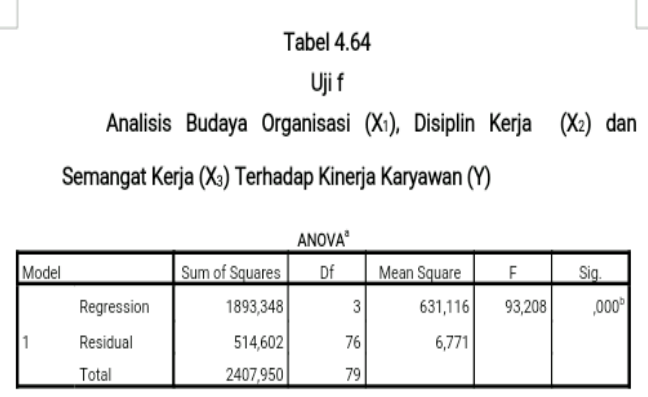

(Sumber : Hasil Pengolahan Data SPSS V.21). 
Berdasarkan tabel hasil perhitungan Statistik uji F diatas, menunjukkan nilai Fhitung > F-tabel yaitu 93.208>2,72 maka dapat disimpulkan bahwa Ho ditolak dan $\mathrm{H}_{\mathrm{a}}$ diterima, Artinya Budaya Organisasi $\left(\mathrm{X}_{1}\right)$ Disiplin Kerja $\left(\mathrm{X}_{2}\right)$ dan Semangat kerja $\left(\mathrm{X}_{3}\right)$ secara bersama-sama berpengaruh positif dan signifikan terhadap Kinerja Karyawan karyawan (Y), dengan demikian nilai Budaya Organisasi, Disiplin Kerja dan Semangat Kerja secara bersama-sama akan semakin meningkat, maka Kinerja Karyawan akan semakin meningkat.

\section{KESIMPULAN DAN SARAN}

\section{Kesimpulan}

Berdasarkan hasil analisis pembahasan, tentang Budaya Organisasi, Disiplin Kerja dan Semangat Kerja terhadap Kinerja Karyawan pada PT Ediral Tritunggal Perkasa Kantor Cikande, penulis menarik kesimpulan sebagai berikut :

1. Budaya Organisasi (X1) memiliki koefisien sebesar 0,908, nilai t-hitung $>$ t-tabel sebesar 13,720>1,66 dengan nilai signifikansi sebesar 0,000, sehingga variabel Budaya Organisasi (X1) memiliki pengaruh yang signifikan terhadap Kinerja Karyawan (Y).

2. Disiplin Kerja (X2) memiliki koefisien sebesar 0,202, nilai t-hitung > t-tabelsebesar 2,482>1,66 dengan nilai signifikansi sebesar 0,015, sehingga variabel Semangat Kerja (X2) memiliki pengaruh yang signifikan terhadap Kinerja Karyawan (Y)

3. Semangat Kerja (X3) memiliki koefisien sebesar 0,175, nilai t-hitung t-tabelsebesar 3,951>1,66 dengan nilai signifikansi sebesar 0,000, sehingga variabel Disiplin Kerja (X2) memiliki pengaruh yang signifikan terhadap Kinerja Karyawan (Y)

4. Hipotesis dapat diterima jika $F_{\text {hitung }}>F_{\text {tabel. }}$ Berdasarkan tabel anova diatas, diperoleh Kinerja karyawan adalah $(93,208>2,72)$, dengan demikian Hipotesis terdapat pengaruh positif dan signifikan antara budaya organisasi, disiplin kerja dan semangat kerja secara bersama-sama terhadap kinerja karyawan pada PT Ediral Tritunggal Perkasa Kantor Cikande.

\section{Saran}

Berdasarkan Kesimpulan di atas, maka penulis dapat memberikan saran-saran sebaagai berikut :

1. Budaya Organisasi yang sudah diterapkan atau diwariskan kepada seluruh karyawan PT Ediral Tritunggal Perkasa Kantor Cikande harus tetap dipertahankan sebagai salah satu nilai untuk meningkatkan Kinerja Karyawan pada PT Ediral Tritunggal Perkasa sehingga dapat menciptakan efisiensi dan kesesuaian karyawan dalam melaksanakan tugas yang dibebankan organisasi/ Perusahaan.

2. Pimpinan pada PT Ediral Tritunggal Perkasa Kantor Cikande hendaknya mempertahankan disiplin kerja khususnya bagi karyawan dalam hal ketepatan waktu, kemampuan melakukan pekerjaan dengan baik serta memiliki tanggung jawab yang tinggi dalam bekerja. Dengan adanya peningkatan disiplin kerja seperti di atas 
tersebut diharapkan para karyawan akan mampu bekerja secarabaik dan penuh semangat sehingga tujuan dari perusahaan dapat dicapai.

3. Secara umum semangat kerja karyawan sudah sangat baik, namun demikian masih perlu peningkatan lagi terutama pada peningkatan kedisiplinan karyawan saat masuk dan pulang kantor, peningkatan kerjasama diantara karyawann terutama pada peningkatan kepekaan karyawan pada rekan sekerja yang mengalami kesulitan kerja maupun mengalami musibah, peningkatan usaha perbaikan atas kesalahan kerja yang mereka lakukan serta turut berperan dalam usaha menjaga dan merawat peralatan kerja agar pekerjaan mereka tidak terganggu akibat kerusakan peralatan kerja tersebut.

4. Terhadap kinerja karyawan hendaknya perintah-perintah yang diberikan oleh atasan dilaksanakan lebih semangat lagi oleh karyawan, hal ini untuk meningkatkan kemampuan secara positif dalam pekerjaannya dengan cara memberikan nilai atau reward bagi karyawan berkinerja baik. Terhadap masalah dan sikap yang dihadapi, karyawan sebaiknya mempersiapkan tindakan-tindakan yang terencana dan sungguh-sungguh jika terdapat permasalahan yang dihadapi oleh perusahaan, hal ini untuk meningkatkan kemampuan, motivasi, dan hasil kerja yang lebih.

\section{DAFTAR PUSTAKA}

Alex S. Nitisemito.2010. manajemen personalia manajemen sumber daya manusia. Edisi ketiga. Jakarta : Ghalia Indonesia.

Arifin dan Barnawi.2012.Etika dan profesi kependidikan.Yogyakarta : Ar-ruzz Media.

Asang, S. 2012. Membangun sumber daya berkualitas (perspektif organisasi publik).

Brilian Internasional, Surabaya.

Darmawan.2013.metode penelitian kuantitatif. Bandung : Remaja Rosdakarya.

Eko, Widodo Suparno.2015.manajemen pengembangan sumber daya manusia. Yogyakarta : Pustaka pelajar.

Hasibuan, Malayu S,P. 2010. Manajemen sumber daya manusia. Jakarta : Bumi Askara. 2011. Manajemen : dasar, pengertian, dan masalah. Jakarta : PT.

Askara.

Husein, umar.2011. metode penelitian untuk skripsi dan tesis bisnis edisi sebelas. Jakarta : PT. Raja Grafindo Persada.

Moeheriono.2012.pengukuran kinerja berbasis komputer. Jakarta : Raja Grafindo Persada. Pasolong, Harbani. 2010. Teori administrasi publik. Bandung : Alfabeta.

Purwanto.2012.metodologi penelitian kuantitatif. Yogyakarta : Pustaka Pelajar.

Rivai, M.B.A . Prof. Dr. Veithzal dan Prof. Dr. Deddy Mulyadi. Msi. 2011. Kepemimpinan dan perilaku organisasi. Jakarta : Raja Grafindo Persada. dan Ella Djauhari sagala.2013. manajemen sumber daya manusia untuk perusahaan. Jakarta : Rajawali pers.

Robbins, Stephen P dan Coulter, Mary.2010.manajemen (edisi kesepuluh). Jakarta : Erlangga.

dan judge, Timothy A.2013. organization behavior edition 15.

New jersey : Person education.

Santoso, Slamet.2010.teori-teori psikologi sosial. Bandung : Refika Aditama.

Sinambela, Lijan Poltak.2012. kinerja pegawai : teori, pengukuran dan implikasi.

Yogyakarta : Graha ilmu. 
2016.Manajemen sumber daya manusia. Jakarta : PT. Bumi Askara.

Sugiyono.2013.metode penelitian kuantitatif. Kuantitatif $R \& D$. Bandung : Alfabet CV. Suharsono.2012.pengetahuan dasar organisasi (cetakan pertama). Jakarta : Universitas atma jaya.

Supriyanto dan Ernawati.2010.pemasaran industry dan kesehatan jasa. CV andi offset.

Sutrisno.2012.manajemen keuangan teori, konsep dan aplikasi. Yogyakarta : Ekonisia.

Wibowo.2010.manajemen kinerja edisi ketiga.Jakarta : Rajawali Pers.

.2012.manajemen kinerja edisi keempat.Jakarta : Rajawali Pers.

.2015.manajemen kinerja. Jakarta : Rajawali pers.

JURNAL - JURNAL

Dunggio Mardjan (2013), Semangat Kerja dan Disiplin Kerja terhadap Produktivitas Kerja Karyawan pada PT. Jasa Raharja (Persero) Cabang Sulawesi Utara, Tersedia : https://ejournal.unsrat.ac.id/index.php/emba/article/view/2726

Mangkunegara dan Latuconsina (2013), Budaya Organisasi, Kecerdasan Emosi dan Kinerja Pegawai Pemerintahan Provinsi DKI Jakarta, Tersedia : http://digilib.mercubuana.ac.id/manager/t!@file_artikel_abstrak/Isi_Artikel_2564247 72010.pdf

Muclisah (2012), Pengaruh Disiplin Kerja dan Pengalaman Kerja terhadap Produktif $\begin{array}{lllll}\text { karyawan } & \text { PT. Indra } & \text { Asia } & \text { Worldwide, } & \text { Tersedia }\end{array}$ https://media.neliti.com/media/publications/248089-pengaruh-disiplin-danpengalaman-kerja-t-e1208c41.pdf

Nurul Qomariyah (2013), Pengaruh Budaya Organisasi , Kepemimpinan dan Komitmen Organisasi terhadap Kinerja Dosen Perguruan Tinggi Swasta di Kabupaten Jember, Tersedia : http://jurnal.unissula.ac.id/index.php/cbam/article/view/172

Shannon Cecilia Y Assagaf dan Lucky O H Dotulong (2013), Pengaruh Disiplin, Motivasi, dan Semangat Kerja Produktivitas Kerja Pegawai Dinas Pendapatan Daerah Kota Manado, Tersedia http://download.portalgaruda.org/article.php?article $=332318 \& v a l=1025 \&$ title $=$ PEN GARUH\%20DISIPLIN 